\title{
COREESPONDENFOF.
}

\section{NATURE OF VOLCANIC HEAT.}

Sir,--In reference to Mr. Scrope's letter in the Geologion Magazine for May, 1874, p. 237, I must exonerate myself from that gentleman's charge of "persistently continuing to saddle him with the advocacy of one or both theories as to the origin of volcanic heat, viz. a liquid nucleus and thin crust, or Hopkins's fiery lakes."

An author's notions are usually gathered from his acknowledged systematic works, and not from scattered magazine articles. I am much mistaken if. Mr. Scrope has not throughout his systematic works adopted one or both of the above theories. On reference to the articles in your Magazine from Mr. Scrope's pen, referred to by you in your foot-note (Geological Magazine, March, 1874, p. 127), as modifying or repudiating the above theories, I am compelled to repeat what I have already stated in your April Number, that nothing contained in them appears to me to justify the statement made by you that I "misapprehended," "and now by Mr. Scrope himself, that $I$ have misrepresented him.

Whether Mr. Scrope's subterraneous reservoirs be left as unex. plained as to their origin, as Hopkins left his lakes, or be assumed to be derived from a rise in geothermal temperature produced by deposition of sediment, makes no difference as respects the validity of the objections which I have urged as equally applicable to both. No body can raise the temperature of another by conductive transference of part of its heat to a temperature as high as its own. If, therefore, the subcortical matter of our globe, as. Mr. Scrope terms it, "passes locally under varying conditions of heat and pressure" .. . . "to a liquid or even vaporous state," there must be matter more deeply situated at a still higher temperature, i.e. there must be a liquid nucleus. Things as essentially different and distinct as are the views which I have enunciated as to the nature and origin of volcanic heat and energy from those anywhere enunciated by $\mathrm{Mr}$. Scrope, may easily be made obscure or confused by fragmentary controversy. I must therefore decline to go further in this direction. I have reduced my own views as to the nature and origin of volcanic heat to the brief and unmistakable form of a definition (Phil. Trans. 1873, vol. i. para. 67, p. 167). Every clear-cut thought and theory can be reduced to the same form. That neither I nor your readers may mistake further (if I have already done so at all) Mr. Scrope's views, will he be good enough to reduce them to a definition? Definitions do not involve any dogmatism, and are extremely serviceable in preventing misconceptions, whether arising from obscurity of expression or of thought.

15 th May, 1874.

Roberit Maluet.

\section{A PROPOSAL FOR A SWISg GEOLOGICAL RAMBLE.}

Sir,-I beg leave to draw the attention of the readers of the Geological Magazinfa to a proposed Swiss tour, which might be a

1 We are content to refer the impartial reader to the articles in question and to Mr. Poulett-Scrope's published work8.-Euit, Grol. Maa. 
very delightful and instructive holiday, and certainly a less expensive trip than one of equal length in dear (very dear).old England or Seotland.

But first I must briefly explain my connexion with the plan. Often, very often, I have fervently wished, during my excursions in the Alps, that a Swiss man of science could have been with me to explain the wonderful geological phenomena surrounding me, instead of having slowly to work out so much as there was time to unravel, with books (of course left in the valley) as my only assistants.

I therefore mentioned amongst my friends how charming it would be to make up a party and. secure the kind assistance of an enthusiastic geologist possessed of familiar knowledge of the localities we should visit.

Many friends fell in with the idea, and asked me to take charge of the party and to occupy the place of the ideal geologist, for whose presence I have so often wished.

Now with regard to the guirlance of the party., I have willingly accepted the part of organizer, for a elimber paying his eighteenth or nineteenth visit cannot be very ignorant of mountain or valley. And I could so far fulfil the geologist's function as to sketch out the nature of what is known of such peints as I have visited. But I entirely decline encroaching upon the functions of a thorough Alpine geologist, without whose aid our trip would lose half its charm.

The season being far advanced, it is I fear too late to form a party for this summer; but if you will allow some space for discussion of details in the Geologioar Magazine, I have no doubt whatever that in 1875 a most effective party could be made up, to include Botanists, Mineralogists, and Entomologists; and I may mention that if only twenty joined together, with circular tickets, a courier could be sent with them, free of expense, to make all hotel and other arrangements-a great saving of anxiety in the tourist season.

Two modes of joining our trip might be adopted: one, to make the whole round decided upon together-by far the most luxurious plan; the other, that persons not wishing to travel with a party should rendezvous with the rest at certain important places. A long experience of travel and many figures now before me enable me to say that, with first-class fares, hotel living, and all reasonable luxuries, the personal expense need not exceed one pound per day for one month, and that for a number it might be a trifle less; whilst strictly economical travellers could well reduce their disbursements.

I will beg such of your readers as may fall in with my hobby, ladies as well as gentlemen, to communicate with me, not, however, with a view to this year's operation. If I act at all in such a matter, it must be with time enough to make the most effective arrangements $I$ can invent, and to communicate with many persons abroad.

In conclusion, let me ask the President of the Geologists' Association what he would think of this extended excursion? I need say no more.

Screntific Club, 7, Sayile Row, W. June 13 th, 1874 .

MarshaLl HaLL. $_{\text {ald }}$ 